\title{
Szymon Syp*
}

\section{Arbitraż a prawo konkurencji - w odpowiedzi doktorowi Tomaszowi Bagdzińskiemu}

\author{
Spis treści \\ I. Wprowadzenie \\ II. W kwestii dochodzenia roszczeń powstałych wskutek naruszenia prawa konkurencji \\ III. W kwestii rozstrzygania przez sąd arbitrażowy sporów z zakresu prawa konkurencji \\ IV. Podsumowanie
}

\section{Streszczenie}

Przedmiotowy artykuł stanowi odpowiedź na artykuł polemiczny autorstwa doktora Tomasza Bagdzińskiego pt. Arbitraż a prawo konkurencji - głos w dyskusji - w stosunku do artykułu pt. Arbitraż a prawo konkurencji - wybrane zagadnienia teoretyczne i praktyczne. W przedmiotowej odpowiedzi koncentruję się na dwóch zagadnieniach: dochodzenia roszczeń powstałych wskutek naruszenia prawa konkurencji oraz rozstrzygania przez sąd arbitrażowy sporów z zakresu prawa konkurencji. W odpowiedzi wskazuję na szereg zagadnień prawnych wymagających rozstrzygnięcia i wpisujących się w zapoczątkowaną dyskusję o wzajemnych powiązaniach pomiędzy prawem konkurencji a arbitrażem.

Klasyfikacja i słowa kluczowe: K21, K42; prawo konkurencji, arbitraż, międzynarodowy arbitraż handlowy, rozstrzyganie sporów, prawo konkurencji UE.

\section{Wprowadzenie}

W artykule pt. Arbitraż a prawo konkurencji - wybrane zagadnienia teoretyczne i praktyczne wspólnie z Piotrem Nowaczykiem ${ }^{1}$ wskazywaliśmy, że wzajemne relacje arbitrażu i prawa konkurencji pojawiają się wówczas, gdy spór handlowy pomiędzy podmiotami dotyka delikatnych kwestii sprowadzających się do następujących pytań: Czy dopuszczalne jest poddanie sporu pod międzynarodowy arbitraż handlowy? Czy arbiter może (a może musi?) stosować prawo konkurencji? 2) Które prawo konkurencji powinien stosować arbiter? Przy tym koncentrowaliśmy uwagę, rozważając przedmiotowe zagadnienia, na perspektywie arbitra jako perspektywie dominującej.

W powyższym świetle warto przywołać konkluzje wynikające z naszego artykułu, na które chcieliśmy zwrócić uwagę społeczności arbitrażowej i zarazem zainicjować dyskusję o wzajemnych powiązaniach pomiędzy prawem konkurencji a arbitrażem. Po pierwsze, wspólnie z Piotrem Nowaczykiem zajęliśmy stanowisko, że spory handlowe w Polsce dotyczące roszczeń z zakresu

\footnotetext{
Doktor nauk prawnych; członek Polskiego Stowarzyszenia Sądownictwa Polubownego; E-mail: szymon.syp@gmail.com.

P. Nowaczyk, Sz. Syp, Arbitraż a prawo konkurencji - wybrane zagadnienia teoretyczne i praktyczne, iKAR 2013, nr 5(2), s. 81 i n.
} 
prawa konkurencji mogą być poddane arbitrażowi na gruncie prawa polskiego oraz arbitrzy mogą stosować również polskie prawo konkurencji. Po drugie, wskazaliśmy, że dystynkcja pomiędzy publicznoprawnym a prywatnoprawnym dochodzeniem roszczeń z prawa konkurencji determinuje ograniczenia w stosowaniu prawa konkurencji przez arbitrów. Arbitraż jest możliwy w stosunku do roszczeń prywatnoprawnych. Arbiter nie może zatem powstrzymać ani uprzedzić właściwych organów antymonopolowych w zakresie ich kompetencji oraz stosowania przez nie prawa konkurencji. W rezultacie arbiter może jedynie decydować o cywilnoprawnych konsekwencjach wynikających z naruszenia prawa konkurencji. Wreszcie, to, które prawo konkurencji powinien stosować arbiter, zależy od określonego stanu faktycznego oraz arbitralnej decyzji arbitra (arbitralnej, lecz uzasadnionej, mając na uwadze rozważania powyżej).

Polemika stanowi esencję wykonywania zawodu prawniczego. W przypadku polemiki dotyczącej artykułu naukowego jest ona trudniejsza, gdyż wymaga od dyskutanta wskazania konkretnych tez, z którymi się nie zgadza (które jego zdaniem są błędne), a co więcej uzasadnienia zajętego stanowiska. Stąd należy docenić podjęcie takich starań przez dr. T. Bagdzińskiego. Przy czym a prima vista wydaje się, że polemika autorstwa dr. T. Bagdzińskiego ${ }^{2}$ stanowi nie tyle polemikę sensu stricto, ile autorski głos w dyskusji na temat wzajemnych relacji pomiędzy arbitrażem a prawem konkurencji, który przejawia się w przedstawieniu argumentów dotyczących publicznoprawnego charakteru regulacji prawa konkurencji i skutków z tego wynikających (w tym zwłaszcza trudności z potencjalną egzekucją rozstrzygnięć zapadłych w arbitrażu). Tym samym, z poziomu par excellence kazuistycznego i konkretnego, dyskutant przenosi rozważania na linii: stosowanie w arbitrażu prawa konkurencji - wyłączenie arbitrażu jako sposobu rozstrzygania sporów z zakresu prawa konkurencji. W tym kontekście dr T. Bagdziński koncentruje swoją polemikę na dwóch zagadnieniach: dochodzenia roszczeń powstałych wskutek naruszenia prawa konkurencji oraz rozstrzygania sporów z zakresu prawa konkurencji. Tym dwóm zagadnieniom chciałbym poświecić niniejszą odpowiedź.

\section{W kwestii dochodzenia roszczeń powstałych wskutek naruszenia prawa konkurencji}

Na początku T. Bagdziński w kwestii dochodzenia roszczeń powstałych wskutek naruszenia prawa konkurencji na drodze sądownictwa polubownego zajmuje stanowisko pozytywne. Innymi słowy, wskazuje On, że nie ma przeszkód w dochodzeniu roszczeń powstałych w związku z naruszeniem prawa konkurencji. Tym samym, Dyskutant zakłada, że najpierw właściwy podmiot (organ ochrony konkurencji) stwierdzi naruszenie prawa konkurencji, a wtórnie (w efekcie takiego naruszenia) jeden podmiot zainicjuje postępowanie arbitrażowe mające na celu dochodzenie roszczeń wskutek takiego naruszenia względem drugiego podmiotu. O ile, takie sformułowanie nie wydaje się kontrowersyjne, o tyle sam Dyskutant zauważa, z czym należy się zgodzić, że powszechność drogi sądownictwa arbitrażowego w przypadku takich sytuacji jest sporna, z uwagi na relacje, jakie łączą przedsiębiorców i brak stosownych klauzul (umownych - dodanie własne) odpowiedniej treści ${ }^{3}$. Wydaje się, że takie rozumowanie będzie miało zastosowanie jedynie do stwierdzenia naruszenia przez właściwy organ zakazu zawierania antykonkurencyjnych porozumień

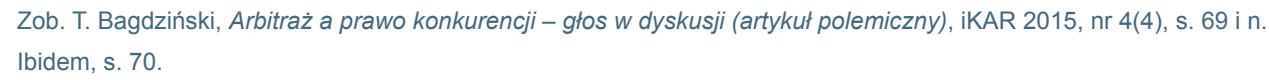


(umów). Co zdaje się też potwierdzać sam Dyskutant, stwierdzając, że „Nie powinno być wątpliwości, że w przypadku stwierdzenia np. deliktu z zakres prawa konkurencji, roszczenia między przedsiębiorcami - pokrzywdzonym praktyką a naruszającym - mogą być dochodzone na drodze arbitrażu (oczywiście, o ile strony sporu łączy umowa ze stosownym zapisem na sąd polubowny)" ${ }^{4}$.

Trudno bowiem wyobrazić sobie dochodzenie roszczeń wskutek naruszenia zakazu nadużywania pozycji dominującej przez przedsiębiorcę (przedsiębiorców - w przypadku pozycji dominującej kolektywnej) z uwagi na brak stosownego zapisu na sąd polubowny pomiędzy „pokrzywdzonym praktyką" a naruszycielem. Nieco inny przypadek, o wiele bardziej interesujący, o którym nie wspomina Dyskutant, a o którym warto wspomnieć nieco szerzej, aktualizowałby się w przypadku wydania przez odpowiedni organ ochrony konkurencji decyzji zakazującej koncentrację przedsiębiorców (np. w przypadku klasycznej transakcji M\&A). Pojawiłoby się wówczas pytanie, na ile możliwe byłoby podniesienie roszczenia (i jakiego rodzaju) przez podmiot (spółkę-cel) względem podmiotu przejmującego (spółkę przejmującą) z uwagi na brak uzyskania przez tę drugą pozytywnej decyzji na koncentrację. Moim zdaniem nie ma przeszkód, aby w klasycznej umowie sprzedaży udziałów/akcji zawrzeć zapis na sąd polubowny, który decydowałby o stosownym odszkodowaniu z uwagi na brak uzyskania przedmiotowej decyzji przez spółkę przejmującą albo zasądzałby karę umowną, którą strony zastrzegły w umowie sprzedaży udziałów/akcji. Ciekaw jestem zdania Dyskutanta w zakresie takiego przypadku i konsekwencji z tym związanych.

\section{W kwestii rozstrzygania przez sąd arbitrażowy sporów z zakresu prawa konkurencji}

Sporo trudności wiąże się z odpowiedzią Dyskutantowi na podniesione uwagi polemiczne z zakresu rozstrzygania przez sąd arbitrażowy sporów z zakresu prawa konkurencji. Przenikają się w polemice bowiem zagadnienia rozstrzygania sporu z zakresu prawa konkurencji ze skuteczności potencjalnego orzeczenia sądu arbitrażowego.

Odnosząc się do pierwszego zagadnienia, wskazać trzeba, że w sposób oczywisty w naszym artykule z Piotrem Nowaczykiem opowiedzieliśmy się za dopuszczalnością arbitrażu in abstracto w stosunku do roszczeń prywatnoprawnych. Arbiter, co słusznie zauważa Dyskutant, nie może zatem powstrzymać ani uprzedzić właściwych organów antymonopolowych w zakresie ich kompetencji oraz stosowania przez nie prawa konkurencji. Arbiter może jedynie decydować o cywilnoprawnych konsekwencjach wynikających z naruszenia prawa konkurencji. Uprzednie wcale nie oznacza, że arbitrzy powinni być wstrzemięźliwi w zakresie dopuszczania sporów z zakresu prawa konkurencji, co zdaje się sugerować Dyskutant, lecz oznacza, że arbitrzy powinni znać swoje ograniczenia związane z rozstrzyganiem sporów z zakresu prawa konkurencji, mając na uwadze współzależność publicznego i prywatnego egzekwowania prawa konkurencji (o współzależności w tym zakresie w literaturze polskiej szeroko wypowiedziała się prof. A. Jurkowska-Gomułka5). Wreszcie Dyskutant zwraca uwagę na wątpliwości, co do zapewnienia wykonalności wyroku sądu arbitrażowego, jako argument za tym, że arbitrzy powinni być wstrzemięźliwi w stosowaniu prawa konkurencji (w domyśle). Jednak sam Dyskutant przyznaje, że konsekwencje związane z brakiem

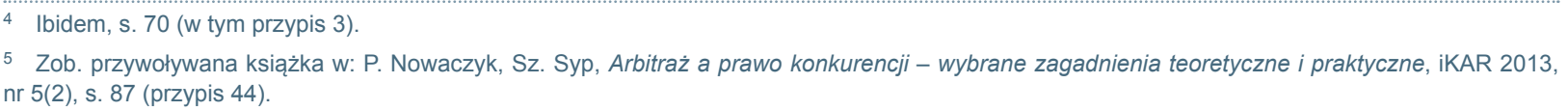


możliwości zapewnienia wykonalności wyroku sądu arbitrażowego nie wpływają negatywnie na samo postępowanie arbitrażowe (i nie uprawniają do jego wznowienia). Stąd brak konsekwencji z tym związanych nie pozwala Dyskutantowi na sformułowanie argumentu przeciwko rozstrzyganiu sporów z zakresu prawa konkurencji przez arbitrów. Konsekwentnie, Dyskutant powraca do koronnego argumentu, wskazującego na fakt, że prawo konkurencji (zwłaszcza w prawie europejskim) jest prawem publicznym (co do zasady). Wyrazić trzeba niekonsekwencję stanowiska Dyskutanta w tym zakresie. Z jednej bowiem strony, Dyskutant twierdzi, że prawo konkurencji w przypadku prawa polskiego jest stosowane $w$ interesie publicznym przez organ ochrony konkurencji i stanowi podstawę dochodzenia roszczeń na drodze prywatnoprawnej ${ }^{6}$. $Z$ drugiej zaś - Dyskutant podnosi, że trudno jest wyobrazić sobie rozstrzyganie przez arbitrów sporów z zakresu prawa konkurencji w interesie publicznym. Nie ulega wątpliwości przecież, że arbitrzy z istoty rzeczy nie rozstrzygają sporów prywatnoprawnych z uwzględnieniem interesu publicznego. Rozumowanie przeciwne powodowałoby przypisanie arbitrom roli organu ochrony konkurencji, co należy oczywiście wykluczyć (a na co wskazuje sam Dyskutant ${ }^{7}$ ). Nie przekonują też argumenty wynikające z faktów, że rozstrzygnięcie arbitrów ma znaczenie dla nieoznaczonej liczby osób czy też jest tajne, a w związku z tym, potencjalni poszkodowani nie dowiedzą się o tym, że zapadło określone rozstrzygnięcie sądu arbitrażowego. Tak jak wspomniałem, arbitrzy orzekają w ramach konkretnego sporu w trybie prywatnoprawnym, a nie publicznoprawnym. Rzekome niedostatki z tego wynikające nie mogą wpływać na prawidłowość rozstrzygnięcie i determinować negatywnych konsekwencji z tego związanych. To przecież istota postępowania arbitrażowego!

Finalnie, odnosząc się do braku zdatności arbitrażowej w kontekście przywołanego przeze mnie oraz Piotra Nowaczyka stanu faktycznego, należy wyrazić zdanie, że efektem rozstrzygnięcia będzie przyznanie określonej stronie odszkodowania bądź też jego brak. Byłoby zupełnie zbyteczne wszczęcie postępowania arbitrażowego, celem którego byłoby rozstrzygnięcie jedynie co do faktu, że dane postanowienie jest czy też nie deliktem antymonopolowym (co na marginesie jest domeną organów ochrony konkurencji).

\section{Podsumowanie}

Pomimo kilku uwag względem sformułowanych przez dr. Tomasza Bagdzińskiego w artykule polemicznym tez, wydaje się, że możliwe jest sformułowanie stanowiska wspólnego, przejawiającego się w twierdzeniu, że w przypadku naruszenia prawa konkurencji stanowiącego o powstaniu szkody u podmiotu poszkodowanego, możliwe jest dochodzenie roszczeń od naruszyciela na zasadach ogólnych, w tym skorzystanie z arbitrażu (w przypadku istnienia określonego klauzuli arbitrażowej). Stąd arbitraż stanowić może narzędzie zapewniające komplementarne względem instrumentów publicznoprawnych, dochodzenie roszczeń z zakresu prawa konkurencji.

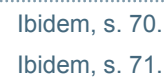

